\title{
INFLUENCE OF PERCEPTION ON THE USE OF NEIGHBOURHOOD PARKS IN MAKURDI.
}

\section{PAPER SUBMITTED TO THE INTERNATIONAL SYMPOSIUM OF THE ANALYTIC HIERARCHY PROCESS HOLDING IN WASGHINTON DC FROM THE $29^{\text {TH }}$ OF JUNE to the $2^{\text {nd }}$ of JULY,2014}

\author{
Irene D. Mngutyo \\ Department of Urban and regional Planning \\ Benue State University \\ Makurdi,Benue State,Nigeria. \\ E-mail: datachi4dan@yahoo.com
}

\begin{abstract}
This study interrogates choice for formal recreation by matching behaviour to perception of Parks in Makurdi.3 of the 8 neighbourhood parks in Makurdi have been abandoned while there is a proliferation of drinking joints coming up in the city.This implies a disconnect between planning intensions and user satisfaction.Maps, Skteches and Observations were used to measure parks utilization.Questionnaires were issued to residents of Makurdi residing withing a mile radius of the public parks to measure perception of parks and choice for recreation. Taro Yamene formula for finite population will be used with projected population of Makurdi to determine sample size.Chi Square and Analytic Heirachy Process (AHP)will be used to analze data.Anticipated findings include what perceptions determine choice for recreation. This is a data base for evaluation of recreation planningin Makurdi
\end{abstract}

Keywords: Neighborhood Parks, Choice, Preferences, Perceptions, Utilization.

\section{Introduction}

This study seeks to interrogate choice for formal recreation in Makurdi by matching perception of parks with choice for recreation. Recreation has been defined severally as an activity that diverts or amuses or stimulates; activity that refreshes and recreates; activity that renews your health and spirits by enjoyment and relaxation (Princeton University, 2013) ; pleasant activity which one enjoys doing in one's spare time for example a sport, hobby.( Kernerman English Multilingual Dictionary, 2006-2013 )Recreation can be carried out anywhere however, this study defines formal recreation activity as recreation activity planned for outside the home. This recreation entails conscious preparation and leaving the home environment to an area designated for recreation such as a park with the intent to enjoy the park resources for recreation 
purposes. Formal recreation may be embarked on individually or in company of friends or family. Formal recreational needs of people in an urban area apart from homes are primarily expected to be met in areas

like parks, stadia, gardens, civic centers, museums, theatres, botanical and zoological centers. These areas are public and accessible to all mainly because they function to aid recreation. Of all these recreation areas, parks are of interest and hence adopted for this study because in urban areas parks can be provided at the neighborhood and even pocket level and thus closer to the people than all the other recreation areas. Also, the range of activities provided in parks caters for all ages and so can be used by both children and adults. This means that they cover a broader spectrum of the society resulting in parks use as most indicative in an urban setting as a choice for recreation. Studies have shown park use as beneficial for physical exercise, social interaction and community cohesion and identity. (Leslie,Cerin and Kremer, 2012; Kwaghsende,2010; DTLR,2002; Nisengard,1996). However despite benefits of parks, it is observed in Makurdi that parks and gardens are seldom used .The town only boasts of neighborhood level of parks, preliminary empirical assessment of these parks indicates that park use is declining as 3 out of the 8 neighborhood parks located in the city have been abandoned and even the five remaining show signs of neglect and some have been converted to events centers. Also, there seem to be a proliferation of drinking joints and restaurants under trees where people congregate in the evening to relax. This development highlights possible scenarios; are people meeting their recreation needs but not in parks? Are parks not drawing patronage for purposes of recreation but for other purposes? Is the western model of provision of neighborhood parks copied in the design of our cities not locally acceptable? How do the residents of Makurdi perceive parks? What do the residents of Makurdi prefer for recreation and relaxation? These questions are indicative that there are gaps between the expectations of park designers and end-user behavior.

\section{Literature review}

Behavior in a spatial environment is dependent on how the environment is perceived. Therefore for design of spatial environment to be effective and efficient planners must understand how the people they 
are planning for perceive their surrounding environment. End-user behavior in spatial environments can be influenced by many factors; however this study links end-user behavior to the perception of the endusers. Literature reviewed highlights theories of environmental psychology as a frame work for linking perception to behavior .( Geographical thought: A Contextual History Of Ideas by Dikshit ,2006)Linking behavior in public places as a basis for urban design(Public Places-Urban Spaces; the dimensions of urban design.by carmona,heath,oc and tiesdall) and( image of the city by lynch,k) though a lot of literature exist on perception and the use of parks this paper aims to fill the gap of achieving increased accuracy in choice, priority and ranking of local perceptions on park use with the application of AHP. This data can then be used to evaluate the suitability of the model of neighborhood parks in use in Makurdi

\subsection{Hypothesis and Objectives.}

Objective in achieving the aims of this research include

1. A feasibility evaluation of park locations in Makurdi.

2. An observation of pattern of activities in parks in Makurdi.

3. Perceptual analysis of park spaces by people in Makurdi

\subsection{Research Design and Methodology}

Data need include demographic data, location of parks, information on what informs choice of location for recreation and perception of existing parks. Neighborhoods surrounding existing parks will be adopted as units for data collection. The Taro Yamane formula will be applied to the chosen neighborhoods census population figures projected to 2012.Random sampling will be done and analysis techniques include chi square and AHP. Studies have also shown perception of park management, park activities, security, distance and the park environment as hindrances to park use these perceptions will form the alternatives . criteria include park management as too expensive and not serving them adequately. Park activites have alternatives like no diverse activites and no activites for adults.security has alternatiive like perception of parks as places that expose one to criminal attack and attack from rodents like snakes which have taken 
over the parks because peolle dont use them.park environment as too far or too near are alternatibes for park environment

\subsection{Data Model Analysis}

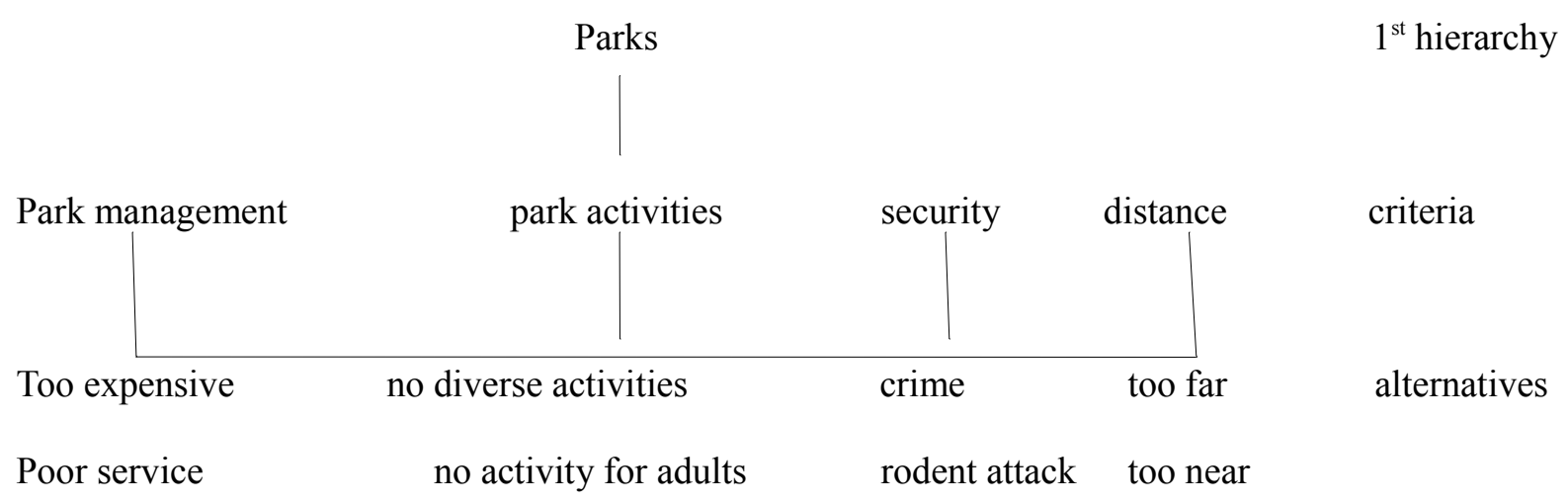

\subsection{Limitations}

Only neighborhood or pocket parks which are the lowest order of parks are used for this study. This is a limitation as larger parks contain diverse activities and so are more attractive.

\subsection{Conclusions}

Theories of environmental psychology are fairly recent. This study may be a contribution to strengthening the theories. Secondly the use of AHP will form data for comparison with other similar studies carried out in Makurdi hence proving or disproving the AHPs claim for more accuracy.

\subsection{Key References}

Dikshit, R.D. (2006). Geographical thought: A Contextual History Of Ideas. Prentice Hall of India, Ashoke Ghosh Publications.

Carmona,M; Heath,T; Oc,T.;Tiesdall,S(2003).Public Places -Urban Spaces; the dimensions of urban design.Architectural Press

Lynch. (1960)The image of the city.MIT Press. Cambridge 